\title{
EFEKTIVITAS MODEL THINK TALK WRITE DAN THINK PAIR SHARE TERHADAP PENINGKATAN KEMAMPUAN KOMUNIKASI MATEMATIS SISWA KELAS 4 SD
}

\author{
Endah Murwatiningsih \\ SD Negeri Lodoyong 02 \\ Endahmurwatiningsih853@gmail.com \\ Wahyudi \\ Program Studi Pendidikan Sekolah Dasar, Universitas Kristen Satya Wacana \\ yudhi@staff.uksw.edu \\ Yohana Setiawan \\ Program Studi Pendidikan Sekolah Dasar, Universitas Kristen Satya Wacana \\ yohana.setiawan05@gmail.com
}

\begin{abstract}
The ability of mathematical communication become one of the comprtency in solving math issue so that it needs to be developed. This research aimed to identify the difference of between the effectiveness of TTW and TPS model towards the development of mathematical communication on $4^{\text {th }}$ grade elementary school students. This research is a pseudoexperimental reasearch designed with Non Equivalent Control Group Design. The used techniques are test and observation with their instruments, question paper and observation paper. The data were analyzed with description analysis and hypothesis test analyzed using Independent Sample t-test, $\mathrm{N}$-gain test, and effectivness test based on the result of $\mathrm{N}$-gain. The result of this research is showing TTW is more effective in improving mathematical communication skills than TPS. This is proven from Sig(2-tailed) the test of Independent Sample T-test is $0,020<0,05$ and the result of $\mathrm{N}$-gain test is TTW $(0,391)$ is bigger than TPS $(0,33)$, reinforced by the results of continued effectiveness tests of 1,184 which means TTW is more effective than TPS.
\end{abstract}

Kata Kunci : Think Talk Write, Think Pair Share, Mathematical Communication

\section{PENDAHULUAN}

Munculnya tantangan pada bidang pendidikan untuk memenuhi perkembangan pembangunan bangsa Indonesia di abad ke-21 menyerukan bentuk-bentuk pembelajaran baru yang dibutuhkan untuk mengatasi tantangan global. Sasaran yang dituju pada abad ke-21 membutuhkan adanya pergerakan tujuan pendidikan dengan cara mempersiapkan siswa untuk menghadapi dunia yang relatif sederhana, tidak berubah dan mampu diprediksi menuju ke kehidupan yang sebaliknya dan membutuhkan keteguhan pikiran dengan kreativitas yang tinggi. Jawaban yang diperlukan untuk harapan dan tantangan tersebut yaitu dengan mewujudkan suatu pendidikan dengan memberikan fasilitas kepada siswa. Hal ini bertujuan agar siswa mampu mengembangkan potensi yang telah dimilikinya. Salah satu fasilitas yang dapat diberikan kepada siswa melalui kegiatan pembelajaran. Kegiatan pembelajaran yang diharapkan dapat mengacu pada 4 karakter belajar di abad ke-21 yaitu communication, collaboration, critical thinking and problem solving, creativity and innovation (Zubaidah, 2016). Istilah yang dikenal dalam menerapkan 4 karakter belajar disebut 4C. (1) Communication memiliki arti dalam pelaksanaaan pembelajaran terdapat komunikasi atau umpan balik antara guru dengan 
siswa. Dengan diberikan kesempatan untuk mengemukakan pendapat dan ide yang dimiliki melalui pengalamannya sendiri. (2) Collaboration yaitu situasi yang diciptakan oleh guru mendorong siswa untuk bekerja sama dalam kelompok dengan penuh tanggung jawab. (3) Critical thinking and problem solving ialah selama proses pembelajaran dapat memacu siswa untuk berpikir kritis dalam memecahkan masalah yang ada dikehidupan sehari-hari. (4) Creativity and innovation adalah terciptanya kondisi siswa dapat berkreasi serta berinovasi dalam pembelajaran sehingga siswa tidak hanya bergantung pada guru. Peran guru dalam hal ini hanya sebagai fasilitator yang menampung semua hasil dari penerapan yang telah dilaksanakan.

Salah satu muatan pembelajaran yang ada di sekolah dasar adalah matematika. Matematika adalah sebuah ilmu universal yang mencakup ide, gagasan dan konsep abstrak yang saling mengikat dengan kehidupan sehari-hari manusia (Indarwati, 2014). Selain itu, matematika juga sebagai dasar ilmu pada perkembangan teknologi hingga masa yang akan datang. Salah satu contoh peran matematika dalam kehidupan sehari-hari yaitu berkaitan dengan penggunaan teknologi untuk menopang aktivitas dalam berbagai bidang. Hampir setiap orang menikmati kecanggihan teknologi yang tersedia di sekitarnya guna mempermudah ataupun mempercepat pekerjaan yang sedang dilakukannya. Dalam dunia pendidikan, sebagian besar siswa beranggapan bahwa matematika adalah salah satu mata pelajaran yang sangat sulit dikarenakan bersifat abstrak. Maka dari itu menjadi kebutuhan bagi siswa untuk memiliki pemahaman tentang matematika sejak berada pada pendidikan sekolah dasar.

Dalam pembelajaran terdapat indikator yang mengukur keberhasilan siswa dalam muatan pembelajaran matematika. Kriteria Ketuntasan Minimal (KKM) sebagai acuan ketercapaian nilai siswa dalam mata pelajaran matematika belum menjamin ketercapaian kemampuan matematika. NCTM (2000:7) menyatakan bahwa terdapat lima kemampuan dasar matematika diantaranya mencakup; kemampuan pemecahan masalah, kemampuan penalaran, kemampuan pemahaman konsep, kemampuan komunikasi matematis dan representasi. Dari hasil pengamatan yang telah dilaksanakan selama kegiatan observasi sebagian besar siswa dalam tiap-tiap kelas hanya memberi tekanan untuk kemampuan prosedural. Dimana mereka beranggapan dapat mengerjakan dengan benar dan hasilnya sesuai dengan jawaban yang disediakan. Hal ini semakin diperkuat dengan adanya sikap siswa yang tidak peduli cara untuk menjelaskan jawaban menggunakan bahasa matematika yang tepat dan benar, cara menuangkan ide atau gagasan kedalam bentuk gambar, cara menjadi pendengar dalam lingkup diskusi dan tidak mau bertanya ketika menghadapi kesulitan mengerjakan. Siswa beranggapan yang terpenting hanyalah jawaban benar dan nilai yang diperoleh melebihi KKM.

Komunikasi matematis adalah kemampuan yang dapat membawa pola dan sifat untuk membangun sebuah pengetahuan baru dengan cara menggambarkan, mendengarkan, menjelaskan, menulis pengetahuan awal sehingga memunculkan kemampuan diri dan aktivitas sosial yang berkaitan masalah matematika (Depdiknas, 2006; Nadhiroh, 2015; NCTM, 2000; Sumarmo, 2013; Walle, 2006; Yuniarti, 2014). Aspek yang digunakan dalam komunikasi matematis meliputi (1) menulis, (2) menggambar, dan (3) menjelaskan. Ketiga aspek tersebut dalam penelitian ini digunakan 
sebagai alat ukur ketercapaian siswa dalam komunikasi matematis. Melalui komunikasi akan tercipta ide yang dapat mengubah sebuah informasi ke dalam bentuk lain, sehingga dapat diterima secara umum misalkan dalam bentuk gambar, diagram dan tabel. Hal ini bertujuan agar membantu siswa untuk mampu memahami ide-ide/gagasan yang terdapat dalam informasi.

Komunikasi matematis temasuk kemampuan berpikir pada tahap menganalisis yang merupakan salah satu bagian dari kemampuan berpikir tingkat tinggi atau yang dikenal dengan Higher Order Thinking Skill (HOTS). Seperti yang kita ketahui bahwa Higher Order Thinking Skill (HOTS) berada ditiga bagian teratas dalam Taksonomi Bloom yang mencakup kemampuan analyze, evaluate and create (Brookhart, 2010). Pada tahap menganalisis siswa dituntut untuk dapat menganalisis permasalahan dan menemukan solusi untuk memecahkannya, sehingga secara otomatis siswa akan diminta untuk mengkomunikasikan hasil yang diperolehnya. Berdasarkan hal itu, tidak diperkenankan untuk mengesampingkan komunikasi matematis pada siswa. Salah satu cara yang dapat dilakukan ialah melalui pemberian evaluasi pada akhir pembelajaran (Sumirat, 2013).

Dalam rangka mengatasi permasalahan tersebut diperlukan upaya untuk memperbaiki pembelajaran matematika melalui penerapan model pembelajaran. Model pembelajaran yang dapat digunakan ialah model TTW yang dibangun melalui proses berpikir (Think), berbicara (Talk), dan menulis (Write) (Suparya, 2019). Tahapan model pembelajaran $T T W$ diawali dari siswa berpikir untuk memproses informasi dalam dirinya melalui proses membaca. Dari proses membaca siswa dapat mengkomunikasikan ide/gagasan dengan cara berbicara dalam kelompok. Pada proses ini siswa dapat menyalurkan ide satu sama lain. Proses terakhir dalam model ini ialah menulis guna menyimpulkan hasil diskusi. Selain itu, siswa juga dapat memuculkan ide-ide baru dari hasil diskusi kelompok lain (Septiani, 2018; Nadhiroh, 2015; Wirawan K, 2016). Dengan menerapkan ketiga proses pada model pembelajaran ini diharapkan dapat meningkatkan kemampuan komunikasi matematis.

Selain model pembelajaran $T T W$, salah satu model yang dapat digunakan untuk meningkatkan komunikasi matematis siswa ialah Think Pair Share (TPS). Pada model $T P S$, siswa bekerja secara berpasangan untuk menyelesaikan dan memecahkan masalah dengan suasana diskusi yang berbeda. Tahapan model TPS dimulai dengan memahami permasalahan secara individu. Pada proses memahami, siswa diberikan waktu untuk mengerjakan LKS. Dari hasil pengerjaan secara individu, siswa dikelompokkan dengan pasangannya untuk berdiskusi tentang hasil pekerjaannya masing-masing. Saat berdiskusi kelompok berpasangan, siswa menentukkan jawaban bersama dalam menyelesaikan masalah. Pada proses penutup dilakukan sharing yang bertujuan untuk membagikan ide dari kelompok berpasangan kepada seluruh kelompok lainnya (Ilham, 2019; Kusumaningrum, 2015; Nadhiroh, 2015; Natalliasari I, 2013; Suhartini, 2015)

Kedua model pembelajaran tersebut termasuk model permbelajaran kooperatif, namun memiliki perbedaan dalam fokus pembelajaran. Model TTW lebih menekankan pada kemampuan siswa untuk mengkomunikasikan hasil pemikirannya serta menuliskan kesimpulan dari hasil dari berbagai pendapat. Dengan demikian, siswa mendapat fasilitas 
untuk memahami terlebih dahulu permasalahan yang dihadapi dan mengeluarkan ide yang dimiliki(Wirawan K, 2016). Berbeda dengan model TPS yang menekankan pada kemampuan siswa untuk berpikir, bertukar ide secara berpasangan dan membagikan hasilnya kepada pasangan lain serta menemukan pemecahan masalah yang lain. Dalam model TPS memungkinkan adanya ide yang berbeda dalam kelompok pasangan lain, sehingga muncul hal yang baru untuk menyelesaikan masalah ketika membagikan informasi.

Dalam penelitian ini akan memberikan gambaran bagaimana efektivitas model $T T W$ dan TPS terhadap kemampuan komunikasi matematis siswa kelas IV SD pada materi keliling dan luas bangun datar persegi, persegi panjang dan segitiga. Melalui penelitian ini diharapkan dapat menjadi salah satu alternatif solusi bagi guru untuk meningkatkan komunikasi matematis pada siswa.

\section{METODE PENELITIAN}

\section{Jenis Penelitian}

Jenis penelitian ini adalah penelitian kuantitatif dengan metode eksperimen semu (quasi eksperimental research). Hal ini dikarenakan tidak seluruh variabel dan kondisi eksperimen dapat diatur serta dikontrol dengan ketat. Desain yang diterapkan yaitu penelitian eksperimen kuasi menggunakan pola non equivalent control group design. Pada desain penelitian ini dapat menggunakan dua kelompok eksperimen yang diawali dengan tes kemampuan awal (pretest). Setelah itu kedua kelompok diberikam treatment dan diakhiri dengan pemberian tes akhir (posttest). Penggunaan sampel pada desain ini tidak dilakukan secara random, hal ini bertujuan untuk melihat kesetaraan kedua kelompok eksperimen. Menurut Johnson \& Christensen (2014) berikut ini adalah gambaran tentang desain penelitian non equivalent control group design.

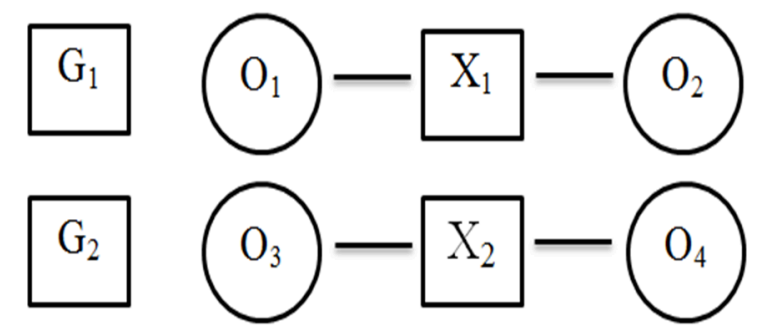

Gambar 1. Non Equivalent Control Group Design

Keterangan:

$\mathrm{G}_{1}$ : Kelompok Eksperimen Pertama

$\mathrm{G}_{2}$ : Kelompok Eksperimen Kedua

$\mathrm{O}_{1}$ : Hasil pretest kelompok eksperimen pertama

$\mathrm{O}_{2}$ : Hasil posttest kelompok eksperimen pertama

$\mathrm{X}_{1}$ : Model 1 dengan Think Talk Write (TTW)

$\mathrm{X}_{2}$ : Model 2 dengan Think Pair Share (TPS)

$\mathrm{O}_{3}$ : Hasil pretest kelompok eksperimen kedua

$\mathrm{O}_{4}$ : Hasil posttest kelompok eksperimen kedua 
Tempat penelitian di Gugus Mahesa Jenar, Kecamatan Ambarawa, Kabupaten Semarang. Populasi dalam penelitian ini adalah siswa kelas IV sebanyak 50 siswa, 27 siswa SDN Lodoyong 02, dan 23 siswa SDN Lodoyong 03. Materi pembelajaran yang digunakan ialah menyelesaikan masalah keliling dan luas daerah persegi, persegi panjang dan segitiga.

Berikut merupakan langkah-langkah yang digunakan dalam penelitian ini: memberikan soal pretest terhadap dua kelompok eksperimen. Hal ini bertujuan untuk memahami kemampuan awal yang dimiliki siswa sebelum diberikan perlakuan. Pada kelompok Ekspeimen 1 diberikan perlakuan menggunakan model TTW dan kelompok Eksperimen 2 menggunakan model TPS. Setelah diberikan perlakuan yang berbeda, kedua kelompok diberikan soal posttest yang bertujuan untuk mengetahui pengaruh dari perlakuan antara kedua model pembelajaran tersebut.

\section{Teknik dan Instrumen Pengumpulan Data}

Teknik pengumpulan data menggunakan teknik tes dan non tes. Teknik tes digunakan untuk mengukur kemampuan komunikasi matematis siswa. Soal tes yang diberikan kepada siswa berbentuk soal uraian. Teknik nontes yang digunakan adalah teknik observasi yang digunakan untuk mengamati kegiatan selama proses pembelajaran berlangsung. Instrumen yang digunakan adalah lembar observasi guru dan siswa.

Disamping itu, juga terdapat langkah-langkah untuk mengumpulkan data diantaranya: menyusun kisi-kisi, menyusun instrumen penelitian, melakukan uji validitas dan reliabilitas menggunakan SPSS 22 for windows, memberikan pretest, memberikan tindakan penelitian, memberikan postest, dan yang terakhir yaitu menganalisis data.

\section{Teknik Analisis Data}

Analisis data dilakukan dalam dua tahapan yaitu analisis deskriptif dan analisis inferensial dengan berbantuan software SPSS 22 for windows. Analisis deskriptif bertujuan untuk mendeskripsikan kondisi kedua kelas eksperimen sebelum dan sesudah diberi perlakuan. Analisis inferensial dilakukan dengan cara melakukan uji beda rata-rata dari kedua kelas ekspterimen dengan diawali uji prasyarat yaitu uji normalitas dan homogenitas. Uji normalitas digunakan untuk mengetahui penyebaran data dari kedua kelas eksperimen. Uji normalitas yang digunakan ialah Shapiro-Wilk. Uji homogenitas bertujuan untuk mengetahui apakah sampel memiliki varian yang sama atau tidak dari kedua kelas eksperimen sebelum dan sesudah diberi perlakuan.

Keefektifan model $T T W$ dan TPS terhadap komunikasi matematis dilakukan uji beda rata-rata dengan menggunakan Independent Sample T-Test dan uji efektivitas menggunakan uji N-Gain. Penggunaan uji Independent Sample T-Test untuk mengetahui apakah terdapat perbedaan rata-rata yang signifikan dari kedua kelompok. Setelah mengetahui ada/tidak ada perbedaan rata-rata dari kedua kelompok eksperimen dilakukan uji N-gain untuk mengetahui kekuatan efektivitas pada model pembelajaran yang diterapkan pada kedua kelompok eksperimen 


\section{HASIL PENELITIAN DAN PEMBAHASAN}

Berdasarkan hasil analisis deskriptif diperoleh data komparasi hasil pengukuran pretest dan posttest kemampuan komunikasi matematis yang disajikan dalam tabel sebagai berikut:

Tabel 1 Komparasi Hasil Pengukuran Kemampuan Komunikasi Matematis

\begin{tabular}{cccc}
\hline \multirow{2}{*}{ Pengukuran } & \multicolumn{2}{c}{ Rata-rata Skor (mean) } & \multirow{2}{*}{ Selisih } \\
\cline { 2 - 3 } & Eksperimen 1 & Eksperimen 2 & 4,35 \\
\hline Pretest & 70,78 & 66,43 & 10,5 \\
\hline Posttest & 82,07 & 77,57 & \\
\hline
\end{tabular}

Berdasarkan data komparasi rata-rata yang disajikan pada Tabel 1, rata-rata skor pretest antara kelompok eksperimen 1 yang diberi perlakuan TTW dan kelompok eksperimen 2 yang diberi perlakuan TPS terdapat selisih sebesar 4,35. Selain itu untuk rata-rata skor posttest antara kedua kelompok eksperimen terdapat selisih sebesar 10,5. Adapun diagram komparasi data kedua kelompok disajikan dalam bentuk gambar.

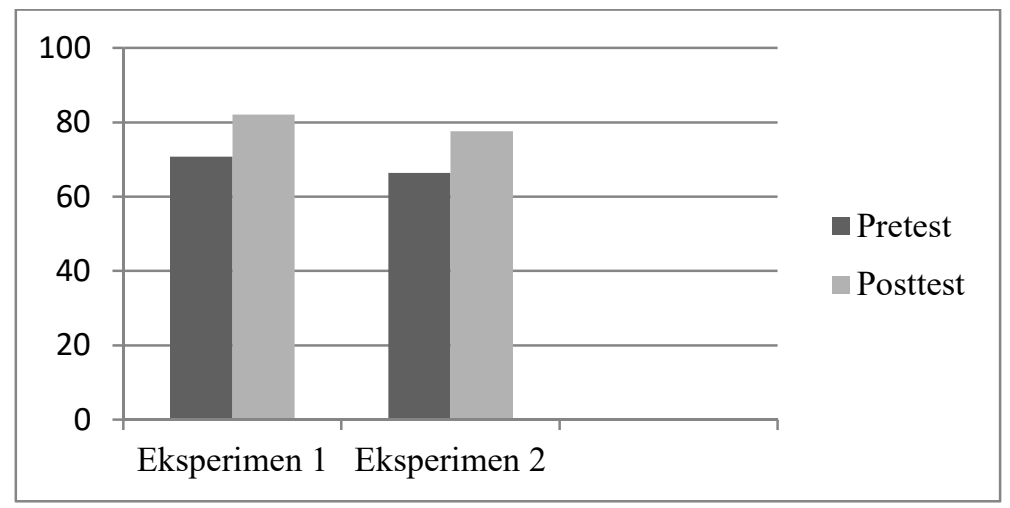

Gambar 2 Komparasi Data Kelompok Eksperimen

Berdasarkan informasi Gambar 2, dapat diketahui adanya peningkatan pada kelompok eksperimen 1 yang menerapkan model $T T W$ maupun kelompok eksperimen 2 dengan model TPS. Dari perolehan data penelitian selanjutnya dilaksanakan uji normalitas dan uji homogenitas sebagai uji prasyarat. Hasil dari uji normalitas dapat dilihat pada tabel 2 sedangkan hasil dari uji homogenitas pada tabel 3 dan 4 .

Tabel 2 Uji Normalitas Kelompok Eksperimen 1 dan Eksperimen 2

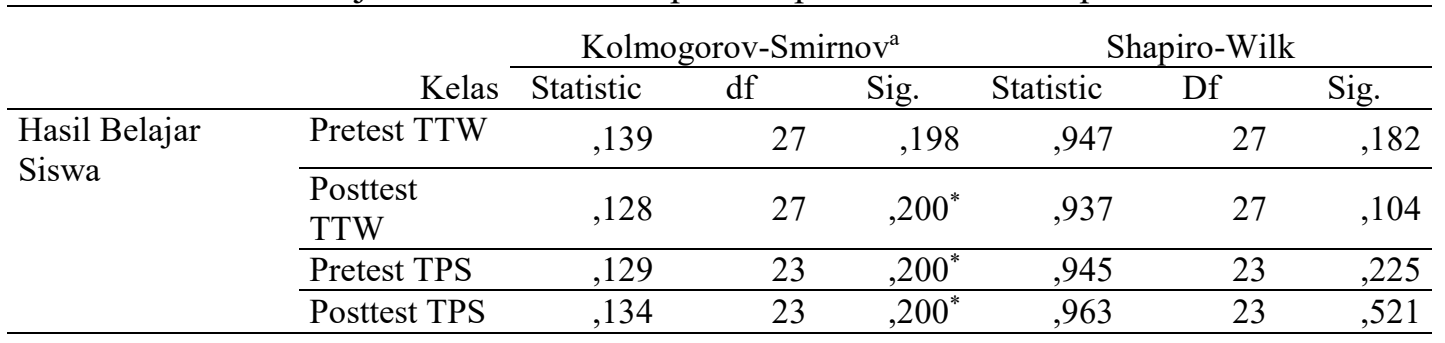

Hasil uji normalitas hasil pretest dan posttest dari kedua kelas eksperimen. Teknik yang digunakan dalam uji normalitas adalah Shapiro-Wilk dengan SPSS 22 for windows jika diperoleh nilai signifikasi $<0,05$ maka data tidak berdistribusi normal dan sebaliknya jika diperoleh nilai signifikasi $>0,05$ maka data berdistribusi normal. Dapat diketahui 
pada tabel 2 menujukkan nilai signifikasi $>0,05$ baik dari hasil pretest maupun posttest dari kedua kelas eksperimen. Maka diperoleh kesimpulan bahwa data memiliki distribusi normal.

Tabel 3 Uji Homogenitas Sebelum Perlakuan

\begin{tabular}{|c|c|c|c|c|c|}
\hline & & $\begin{array}{l}\text { Levene } \\
\text { Statistic }\end{array}$ & df1 & df2 & Sig. \\
\hline \multirow{4}{*}{$\begin{array}{l}\text { Hasil } \\
\text { Pretest }\end{array}$} & Based on Mean & 5,323 & 1 & 48 &, 025 \\
\hline & Based on Median & 5,045 & 1 & 48 & ,029 \\
\hline & $\begin{array}{l}\text { Based on Median } \\
\text { and with adjusted df }\end{array}$ & 5,045 & 1 & 45,267 & 030 \\
\hline & $\begin{array}{l}\text { Based on trimmed } \\
\text { mean }\end{array}$ & 5,220 & 1 & 48 & 027 \\
\hline \multicolumn{6}{|c|}{ Tabel 4 Uji Homogenitas Setelah Perlakuan } \\
\hline & & $\begin{array}{c}\text { Levene } \\
\text { Statistic }\end{array}$ & df1 & $\mathrm{df} 2$ & Sig. \\
\hline \multirow{4}{*}{$\begin{array}{l}\text { Hasil } \\
\text { Posttest }\end{array}$} & Based on Mean & 4,925 & 1 & 48 &, 031 \\
\hline & Based on Median & 4,651 & 1 & 48 &, 036 \\
\hline & $\begin{array}{l}\text { Based on Median } \\
\text { and with adjusted } \\
\text { df }\end{array}$ & 4,651 & 1 & 46,844 & ,036 \\
\hline & $\begin{array}{l}\text { Based on trimmed } \\
\text { mean }\end{array}$ & 4,946 & 1 & 48 & ,031 \\
\hline
\end{tabular}

Berdasarkan informasi Tabel 3 dan Tabel 4 diperoleh hasil uji homogenitas menggunakan metode Lavene's Test. Dengan memilih salah satu interprestasi statistik yang didasarkan pada rata-rata (Based on Mean). Pada tebel 3 menunjukkan hasil uji homogenitas sebelum perlakuan memperoleh nilai signifikasi 0,025 dimana $<0,05$ yang berarti bahwa kedua kelas sebelum perlakuan tidak memiliki varian yang sama atau tidak homogen. Sedangkan pada tebel 4 menunjukkan hasil uji homogenitas setelah perlakuan memperoleh nilai signifikasi 0,031 dimana $<0,05$ yang berarti bahwa kedua kelas sebelum perlakuan tidak memiliki varian yang sama atau tidak homogen.

Uji prasyarat yang telah dilakukan bertujuan untuk menentukan jenis uji perbedaan rata-rata yang akan digunakan. Dalam penelitian ini uji perbedaan rata-rata menggunakan uji independent sample $T$ test, syarat yang pokok untuk menggunakan uji ini ialah data berdistribusi normal dan homogen (tidak mutlak). Pada syarat kedua jika data diketahui tidak homogen, maka tetap dapat menggunakan independent sample T test pada equal variances not assumed. Setelah memenuhi uji prasyarat yang telah dilakukan dapat diketahui bahwa data berdistribusi normal dan tidak homogen. Kemudian dilakukan analisis uji T menggunakan independent sample T test dengan bantuan software SPSS 22 for windows. Hasil dari analisis uji T disajikan dalam bentuk tabel sebagai berikut: 
Tabel 5 Hasil Analisis Uji T dengan Independent Sample T-Test

\begin{tabular}{|c|c|c|c|c|c|c|c|c|c|c|}
\hline & & \multicolumn{4}{|c|}{$\begin{array}{c}\text { Levene's Test } \\
\text { for Equality of } \\
\text { Variances }\end{array}$} & \multicolumn{5}{|c|}{ t-test for Equality of Means } \\
\hline & & \multirow[b]{2}{*}{$\mathrm{F}$} & \multirow[b]{2}{*}{ Sig. } & \multirow[b]{2}{*}{$\mathrm{t}$} & \multirow[b]{2}{*}{ Df } & \multirow{2}{*}{$\begin{array}{l}\text { Sig. (2- } \\
\text { tailed) }\end{array}$} & \multirow{2}{*}{$\begin{array}{c}\text { Mean } \\
\text { Differ } \\
\text { ence }\end{array}$} & \multirow{2}{*}{$\begin{array}{c}\text { Std. } \\
\text { Error } \\
\text { Differe } \\
\text { nce }\end{array}$} & \multicolumn{2}{|c|}{$\begin{array}{c}95 \% \text { Confidence } \\
\text { Interval of the } \\
\text { Difference }\end{array}$} \\
\hline & & & & & & & & & Lower & Upper \\
\hline \multirow[t]{2}{*}{$\begin{array}{l}\text { Hasil } \\
\text { Posttest }\end{array}$} & $\begin{array}{l}\text { Equal } \\
\text { variances } \\
\text { assumed } \\
\end{array}$ & 4,925 &, 031 & 2,344 & 48 & 023 & 4,509 & 1,923 & ,642 & 8,376 \\
\hline & $\begin{array}{l}\text { Equal } \\
\text { variances } \\
\text { not assumed }\end{array}$ & & & 2,407 & $\begin{array}{r}46,6 \\
91\end{array}$ &, 020 & 4,509 & 1,873 &, 740 & 8,278 \\
\hline
\end{tabular}

Berdasarkan data Tabel 5, hasil uji $\mathrm{T}$ menggunakan independent sample $T$ test menunjukkan hasil bahwa thitung sebesar 2,407 dengan signifikasi pada kolom Sig(2tailed) sebesar 0,020. Perbedaan rata-rata dari kelompok mean diference sebesar 4,509. $\mathrm{T}_{\text {tabel }}$ yang diperoleh dari data diatas adalah 2,011. Data ini menunjukan bahwa signifikasi kedua kelompok eksperimen adalah $0,020<0,05$, maka dapat dinyatakan bahwa kedua kelompok eksperimen memiliki perbedaan rata-rata yang signifikan. Untuk memperkuat hasil ini dilanjutkan uji normalitas gain (N-gain). Rumus yang digunakan dalam uji normalitas Gain yaitu rumus Hake yang dapat dilihat pada tabel berikut.

\begin{tabular}{|c|c|c|}
\hline \multirow{5}{*}{ Keterangan : } & \multicolumn{2}{|c|}{ S posttest $-S$ pretest } \\
\hline & \multicolumn{2}{|c|}{$N-$ gain $=\frac{S \max -S \text { pretest }}{S}$} \\
\hline & S posttest & : Skor posttest \\
\hline & S pretest & : Skor pretest \\
\hline & $\mathrm{S} \max$ & : Skor maksimum ideal \\
\hline & \multicolumn{2}{|c|}{ Tabel 6 Kategori Perolehan Skor N-gaain } \\
\hline & Batasan & Kategori \\
\hline & $\mathrm{g}>0,7$ & Tinggi \\
\hline & $0,3<\mathrm{g} \leq 0,7$ & Sedang \\
\hline & $\mathrm{g}<0,3$ & Rendah \\
\hline
\end{tabular}

Hasil uji normalitas gain kelas eksperimen 1 menunjukkan bahwa rata-rata kelas eksperimen 1 mengalami peningkatan sebesar 0,391 yang berarti N-gain rata-rata kelas eksperimen 1 termasuk peningkatan kategori sedang. Pada kelas eksperimen 2 memiliki rata-rata 0,33. Hal ini menunjukkan bahwa pada kelas eksperimen 2 mengalami peningkatan kategori sedang. Secara keseluruhan siswa memiliki peningkatan nilai kemampuan komunikasi matematis dalam kategori sedang dan terdapat 10 orang yang mengalami peningkatan dalam kategori rendah. Dari hasil tersebut perlu diketahui tingkat keefektifan dari kedua model pembelajaran yang diterapkan menggunakan rumus berikut ini :

$$
\text { Efektivitas }=\frac{N-\text { gain Kelompok Eksperimen } 1(T T W)}{N-\text { gain Kelompok Eksperimen 2(TPS) }}
$$


Dengan kriteria pengambilan keputusan sebagai berikut :

1. Jika efektivitas $>1$ maka terdapat perbedaan efektivitas dimana menerapkan model TTW dinyatakan lebih efektif daripada model TPS.

2. Jika efektivitas $=1$ maka tidak terdapat perbedaan efektivitas dimana menerapkan model TTW dan TPS.

3. Jika efektivitas $<1$ maka terdapat perbedaan efektivitas dimana menerapkan model TPS dinyatakan lebih efektif daripada model $T T W$.

Berdasarkan rumus diatas dilakukan perhitungan uji efektivitas sebagai berikut :

$$
\text { Efektivitas }=\frac{0,391}{0,33}=1,184
$$

Berdasarkan hasil perhitungan uji efektivitas menunjukkan bahwa kedua kelompok sebesar 1,184. Dengan demikian dapat dikatakan terdapat perbedaan efektivitas dimana menerapkan model $T T W$ dinyatakan lebih efektif daripada model TPS. Setelah mengetahui efektivitas dari kedua kelompok eksperimen selanjutnya dilakukan uji hipotesis. Langkah-langkah dalam pengujian hipotesis bertujuan untuk menentukan apakah hipotesis diterima atau ditolak.

$\mathbf{H}_{\mathbf{0}}=$ Tidak terdapat perbedaan efektivitas yang signifikan terhadap kemampuan komunikasi matematis pada kelas 4 SD dalam pembelajaran model pembelajaran $T T W$ dan $T P S$

$\mathbf{H}_{\mathbf{a}}=$ Terdapat perbedaan efektivitas yang signifikan terhadap kemampuan kemampuan komunikasi matematis pada kelas 4 SD dalam pembelajaran model pembelajaran $T T W$ dan TPS.

Kriteria pengambilan keputusan:

1. $\mathrm{H}_{0}$ ditolak jika $\mathrm{N}$-gain Kelas Eksperimen $1=\mathrm{N}$-gain Kelas Eksperimen 2

2. $\mathrm{H}_{\mathrm{a}}$ diterima jika $\mathrm{N}$-gain Kelas Eksperimen $1 \neq \mathrm{N}$-gain Kelas Eksperimen 2

Sesuai dengan kriteria pengujian hipotesis, bahwa nilai efektivitas menunjukkan 1,184 sehingga $\mathrm{H}_{0}$ ditolak dan $\mathrm{H}_{\mathrm{a}}$ diterima. Oleh karena itu maka hasil uji hipotesis menyatakan ada perbedaan efektivitas model pembelajaran Think Pair Share dan Think Talk Write terhadap peningkatan komunikasi matematis siswa kelas IV SD. Sehingga dapat disimpulkan bahwa model $T T W$ lebih efektif terhadap kemampuan komunikasi matematis pada siswa kelas $4 \mathrm{SD}$.

Berdasarkan hasil penelitian, model Think Talk Write dan Think Pair Share dapat meningkatkan komunikasi matematis siswa. Hal ini dikarenakan siswa memiliki ruang untuk: 1) menyampaikan ide matematis secara lisan, tulisan dan menggambar, 2) mengubah pemahaman mereka dari bentuk lisan/tulisan ke dalam bentuk gambar, 3) menggunakan penyelesaian yang sesuai untuk memecahkan masalah. Hal ini senada dengan Mahmudi (Tamyah, 2015) yang mengungkapkan bahwa ketika siswa ditantang untuk berpikir dan berkomunikasi dengan siswa lain secara lisan maupun tertulis, maka siswa secara tidak langsung memiliki kemampuan komunikasi yang baik untuk membuat ide-ide matematika lebih terstruktur dan mudah dipahami. 
Keberhasilan model Think Talk Write dan Think Pair Share untuk meningkatkan kemampuan komunikasi matematis siswa juga dipengaruhi oleh kesempatan siswa untuk berkomunikasi dan menyampaikan konsep ide ataupun pemahamannya terhadap materi yang disajikan. Dengan adanya proses komunikasi siswa secara mudah mengutarakan ide setelah berpikir atau memahami materi. Hal ini sejalan dengan Azizah (2018) menyatakan bahwa siswa yang memiliki pengalaman berbagi ide dan membantu teman menghadapi kesulitan dalam kelompok menggambarkan adanya diskusi yang menjadi sarana berkomunikasi antar kelompok maupun guru.

Selain itu, keberhasilan dalam penelitian ini juga didukung dengan meningkatnya skor pretest ke posttest sehingga dapat diketahui adanya perbedaan yang signifikan sebelum dan sesudah penerapan model Think Talk Write dan Think Pair Share. Maka dilakukan analisis data yang menunjukkan bahwa model Think Talk Write memiliki peningkatan lebih tinggi dibandingkan model Think Pair Share. Dari hasil tersebut dapat dikatakan bahwa model Think Talk Write lebih efektif dalam meningkatkan komunikasi matematis siswa kelas 4 SD. Hasil ini menguatkan penelitian Sumirat (2013); Nadhiroh (2015); Azizah (2018); Septiani (2018) yang menyatakan bahwa model pembelajaran Think Talk Write dapat meningkatkan proses serta hasil belajar dan merangsang ide-ide yang dimiliki siswa. Selain itu, melalui model Think Talk Write dapat mengasah keterampilan berpikir siswa dan kemampuan komunikasi baik secara lisan maupun tulisan secara matematis.

\section{SIMPULAN DAN SARAN}

Berdasarkan hasil penelitian dan pembahasan dapat disimpulkan bahwa terdapat perbedaan efektivitas kemampuan komunikasi matematis dalam menerapkan model Think Talk Write (TTW) dan Think Pair Share (TPS). TTW lebih efektif meningkatkan kemampuan komunikasi matematis dibandingkan TPS. Hal ini dibuktikan dari $\operatorname{Sig}(2-$ tailed) uji $t$ Independent Sample T-Test sebesar 0,020 0,020<0,05 yang berarti terdapat perbedaan rata-rata kedua kelompok. Hasil uji N-gain peningkatan kemampuan komunikasi matematis kelompok eksperimen 1 (TTW) 0,391 lebih besar dibandingkan kelompok eksperimen 2 (TPS) sebesar 0,33. Diperkuat dengan hasil uji efektivitas lanjutan sebesar 1,184, yang memperkuat bahwa TTW lebih efektif meningkatkan kemampuan komunikasi matematis siswa SD kelas V. Hal ini terjadi karena TTW lebih banyak memberi kesempatan kepada siswa untuk menyampaikan ide-ide yang dimiliki dengan keterampilan berpikir tingkat tinggi serta memberikan kesempatan siswa menyampaikan hasil secara lesan maupun tulisan.

Saran yang dapat diberikan sesuai hasil penelitian ini adalah, TTW hendaknya dapat terus digunakan dalam pembelajaran di Sekolah Dasar. Hal ini dikarenakan TTW dapat meningkatkan kemampuan komunikasi matematis siswa. Namun perlu diperhatikan dalam penerapan harus disesuaikan dengan karakteristik dan kondisi lingkungan sekolah. 


\section{DAFTAR PUSTAKA}

Azizah, S. N., \& Wahyudi, W. (2018). Penerapan Model TTW Berbasis Saintifik Untuk Meningkatkan Hasil Belajar Tema Kebersamaan Siswa Kelas II. JINoP (Jurnal Inovasi Pembelajaran), 4(2), 160-171.

Brookhart, S. M. (2010). How To Assess Higher Order Thingking Skills In Your Classroom. Alexandria: ASCD.

Depdiknas, P. K. B. (2006). Kurikulum Tingkat Satuan Pendidikan. Jakarta: Depdiknas.

Ilham, I., \& Budhi, W. (2019). Pengaruh Model Pembelajaran Kooperatif Tipe Think Pair Share Terhadap Prestasi Belajar Fisika Pokok Bahasan Getaran Dan Gelombang. Compton: Jurnal Ilmiah Pendidikan Fisika, 5(1).

Indarwati, D., Wahyudi, \& Ratu, N. (2014). Peningkatan Kemampuan Pemecahan Masalah Matematika Melalui Penerapan Problem Based Learning Untuk Siswa Kelas V SD. Satya Widya, 17-27.

Kusumaningrum, R., Budiyono, B., \& Subanti, S. (2015). Eksperimentasi Model Pembelajaran Kooperatif Tipe Two Stay Two Stray (TSTS), Numbered Heads Together (NHT), dan Think Pair Share (TPS) Pada Materi Lingkaran Ditinjau Dari Kreativitas Belajar Matematika Siswa SMP Negeri di Kabupaten Sukoharjo. Jurnal Pembelajaran Matematika, 3(7).

Marviana, N. I., Wahyudi, W., \& Indarini, E. (2018). Efektivitas Model CIRC Dan GGE Terhadap Kemampuan Pemecahan Masalah Matematika SD. JUSTEK| Jurnal Sains \& Teknologi, 1(1), 89-94.

Nadhiroh, H., Jamiah, Y., \& Yani, A. (2015). Model Pembelajaran TTW dan TPS Terhadap Kemampuan Komunikasi Matematis Siswa Dalam Materi Bangun Datar. Jurnal Pendidikan dan Pembelajaran, 4(9).

Natalliasari, I. (2013). Penggunaan Model Pembelajaran Kooperatif Tipe Think Pair Share (TPS) Untuk Meningkatkan Kemampuan Penalaran Dan Pemecahan Masalah Matematis Siswa MTs (Doctoral dissertation, Universitas Terbuka).

NCTM. 2000. Principles and Standards for School Mathematics. [Online]. Tersedia: http://www.nctm.org/uploadedFiles/Standards_and_Positions/PSSM_ExecutiveSu mmary.pdf. (11 November 2015)

Septiani, A., Wahyudi, W., \& Indarini, E. (2018). Penerapan Metode Think Talk Write Untuk Meningkatkan Kemampuan Komunikasi Dan Hasil Belajar Tema Daerah Tempat Tinggalku Siswa Kelas 4 Sdn Tegalrejo 01. KALAM CENDEKIA PGSD KEBUMEN, 6(3.1).

Suhartini, S. (2015). Peningkatan Keterampilan Menulis Naskah Drama Satu Babak Menggunakan Model Think-Pair-Share Berbantuan Alat Peraga Gambar Berseri. Satya Widya, 31(2), 83-89.

Sumirat, L. A. (2013). Efektifitas Strategi Pembelajaran Kooperatif Tipe Think-TalkWrite (TTW) Terhadap Kemampuan Komunikasi Dan Disposisi Matematis Siswa (Doctoral dissertation, Universitas Terbuka). 
Suparya, I. K. (2019). Pengaruh Model Pembelajaran Kooperatif Tipe Think Talk Write (TTW) Terhadap Hasil Belajar Dan Kemampuan Berpikir Kritis Pada Pembelajaran IPA di Sekolah Dasar. Jurnal Widyacarya, 2(2), 19-24.

Tamyah, A., Asnawati, R., \& Djalil, A. (2015). Efektivitas Model Problem Based Learning Ditinjau Dari Kemampuan Komunikasi Matematis Siswa. Jurnal Pendidikan Matematika Unila, 3(2).

Walle, J. A. 2006. Matematika Sekolah Dasar dan Menengah Jilid 2. Jakarta:Penerbit Erlangga.

Wirawan, K. (2017, June 2). caridokumen. Retrieved November 28, 2018, from caridokumen: https://caridokumen.com/download/model-pembelajarankooperatif-ttw-cooperative-ttw-learning-model-_5a4619beb7d7bc7b7aef058c pdf

Yuniarti, Y. (2014). Pengembangan Kemampuan Komunikasi Matematis Dalam Pembelajaran Matematika Di Sekolah Dasar. EDUHUMANIORA: Jurnal Pendidikan Dasar, 6(2).

Zubaidah, S. (2016, December). Keterampilan Abad Ke-21: Keterampilan Yang Diajarkan Melalui Pembelajaran. In Seminar Nasional Pendidikan Dengan Tema "Isu-Isu Strategis Pembelajaran MIPA Abad (Vol. 21, No. 10). 